The Penal world in the French Empire : a comparative study of French transportation and its legacy in Guyana and New Caledonia

\author{
Corresponding author: \\ Isabelle Merle \\ Université Aix-Marseille \\ CNRS-EHESS, \\ CREDO UMR 7308, \\ 13331, Marseille \\ France \\ E-mail:
}

Marine Coquet

EHESS (Paris)

E-mail : marine.coquet@ehess.fr 


\title{
The Penal world in the French Empire : a comparative study of French transportation and its legacy in Guyana and New Caledonia
}

Isabelle Merle and Marine Coquet

\begin{abstract}
From respectively 1852 to 1938 and 1863 to 1897, Guyana and New Caledonia received tens of thousands of men and hundreds of women sentenced to hard labour, deportation or relegation on their soil. This article aims to compare the social history of these two penal colonies, something which has never been done specifically. Transportation and its effects on the populating of both countries are here analysed in context: in the colonial situation experienced by the two territories, in contact with other populations, whether indigenous, imported or colonial. Subjected to the same rural utopia defended by the 1854 act on convict transportation, the two colonies nonetheless evolved very differently. It is this we shall be investigating in a close field study. With this "ground level" approach, we hope to reveal how original colonial societies were formed out of these particular and remarkable penal experiments.
\end{abstract}

Key words : Guyana, New Caledonia, bagne, penal colony, french transportation, convicts, colonial history, settlers, natives, indentured labour, penal and free colonisation.

\section{Introduction}

The bagnes experience in the penal colonies of Guyana and New Caledonia have aroused curiosity for a long time. ${ }^{1}$ Already in the nineteenth century and at the turn of the $\mathrm{XX}^{\text {th }}$, the prison colonies of Guyana and New Caledonia, as well as the question of transportation and relegation, had become the subject of an abundant literature. Experts, jurists or administrators debated the evaluation and justification for the system, as well as the the best means to implement it. Many of these authors were not unaware of the preceding British history of transportation of condemned criminals to

1 The machinery of the different institutions covered by the generic term of "bagnes",harbour bagnes, colonial bagnes, military bagnes and child bagnes, was the subject of a recent work/synthesis by Michel Pierre, Le temps des bagnes, 1748-1953, Paris, Tallandier, 2017, 526 p. 
Australia $^{2}$ and regarded the two French colonies as part of the same experiment ${ }^{3}$. Following Albert Londres' sensational report in 19234, journalists paved the way for public debate and protests, whileprovoking a proliferation of accounts which left a deep mark on the imagination of the times: that of a violent, insalubrious and wretched Guyanese bagne (prison camps) The novel by Leon Uris, Papillion, to cite the most famous, would echo this tale. On the other hand, the Caledonian bagne however sank into oblivion from the 1930s onwards.

After the Second World War, when the camps in Guyana closed, France preferred to suppress this past which few historians revisited. The 1970s and 80s saw a resurgence in studies on confinement and prisons, particularly under the influence of Michel Foucault ${ }^{5}$ and Michelle Perrot ${ }^{6}$ seminal works. In their wake, came the publication on royal galleys ${ }^{7}$ by André Zysberg and the beginning of a re-examination of the history of colonial bagnes ${ }^{8}$. The focus was then placed on how prison institutions functioned and on the populations which the bagne had attracted. Guyana, which received the large majority of convicts for more than ninety years, naturally became the subject of particular attention. The works of Michel Pierre ${ }^{9}$, Danielle Donet-Vincent ${ }^{10}$, Pascale Cornuel ${ }^{11}$, Marion F. Godfroy-Tayard de Borms ${ }^{12}$, gave an account of how the Guyanese

\footnotetext{
${ }^{2}$ See, for example: Ernest Blosseville, Histoire des colonies pénales de l'Angleterre en Australie, Paris, A. Le Clère, 1831, 596 p. Many contemporary studies of French transportation also deal with the British experience. These include : A. Franceschi, De l'organisation locale de la transportation, Ph.D. thesis, Laval, Eugène Jamin, 1895, 166 p., Francis Brouilhet, De la transportation, son organisation actuelle et ses résultats, Ph.D. thesis, Paris, Arthur Rousseau, 1899, 256 p.

${ }^{3}$ See among others: Maurice Pain, Colonisation pénale : un problème colonial, Paris, La tribune des colonies et des protectorats, 1892, 107 p., Henri Cor, Contribution à l'étude des questions coloniales. De la transportation considérée comme moyen de répression et comme force colonisatrice, Ph.D. thesis, Paris, Henri Jouve, 1895, 180 p., Armand Calmel, La colonisation pénale, Ph.D. thesis, Bordeaux, Y. Cadoret, 1899, 240 p., Paul Mimande, Nos colonies pénitentiaires, Rouen, Léon Gy, 1907, 32 p.

${ }^{4}$ And published as a book in 1924: Albert Londres, Au bagne, Paris, Le Serpent à Plumes, 2003 [1924], $249 \mathrm{p}$.

5 Michel Foucault, Surveiller et punir. Naissance de la prison, Paris, Gallimard, 1975, 360 p.

${ }^{6}$ Michelle Perrot, Les ombres de l'histoire, crimes et châtiments au XIXe siècle, Paris, Flammarion, 2001 [1984], $428 \mathrm{p}$.

${ }^{7}$ André Zysberg, Les galériens. Vies et destin de 60000 forçats sur les galères de France, 1680-1748, Paris, Seuil, 1987, $478 \mathrm{p}$.

${ }^{8}$ In the form of articles in two works edited by Jacques-Guy Petit, La prison, le bagne et l'histoire, Genève, Médecine et Hygiène, 1984, 233 p., and Histoire des galères, bagnes et prisons : XII ${ }^{e}-X X^{e}$ siècles. Introduction à l'histoire pénale en France, Paris, Privat, 1991, 368 p.

${ }_{9}^{9}$ Michel Pierre, Bagnards, la terre de grande punition, Cayenne 1852-1953, Paris, Autrement, 2000, 262 p., (first published, Edition Ramsay, Paris,1982).

${ }^{10}$ Danielle Donet-Vincent, De soleil et de silences. Histoire des bagnes de Guyane, Paris, La Boutique de l'Histoire, 2003, 551 p.

11 Pascale Cornuel, « Guyane française : du "paradis" à l'enfer du bagne » in Marc Ferro, Le livre noir du colonialisme, XVI ${ }^{e}-X X I^{e}$ siècle : de l'extermination à la repentance, Paris, Robert Laffont, 2003, pp. 208-219. 12 Marion F. Godfroy-Tayard de Borms, Bagnards, Paris, Tallandier, 2003, 297 p.
} 
bagne came into being and functioned from its creation to its abolition. More recently, Jean-Lucien Sanchez ${ }^{13}$ has thrown light on the specific history of relegation in Guyana which until then had been made little of. Less historians took an interest in the penal experiment in New Caledonia. Louis-José Barbançon ${ }^{14}$ revisited the 1854 transportation act and concentrated more specifically on prison institutions in New Caledonia. The importance of political deportation in New Caledonia has been the subject of several works $^{15}$. As for Odile Krakovitch, she has studied the fate of women convicts in the two colonies ${ }^{16}$. Stephen A. Toth has focussed on the penal colony guards in both colonies to. ${ }^{17}$ As a result, todaythe institutional history of the bagnes in Guyana and New Caledonia is well known.

However, the approach adopted by Isabelle Merle in 1995 was part of a different perspective, going beyond the mere history of the bagne to look at free and penal settler colonisation in New Caledonia ${ }^{18}$. This work links the bagne system with the social fabric of which it was part, that of a colony in the process of formation, colonised by France in 1854, which the prison camps helped to shape. Marine Coquet's recent PhD thesis on the penal district of Saint-Laurent-du-Maroni applies this approach to Guyana. Basing her work on a dialogue between national and local archives, she studied the making of a social world in which the bagne and the bagnards interacted with the colony and its heterogeneous population ${ }^{19}$.

The paper we propose here, aims to make a clearer connection between the social and penal histories of the French Empire's two prison colonies, until now generally

13 Jean-Lucien Sanchez,, À perpétuité. Relégués au bagne de Guyane, Paris, Vendémiaire, 2013, 392 p. See also Denise Rodriguez, « The Experience of Relegation in the French Penal Colonies (1885-1953), unpublished doctorale dissertation, Penn State University, 2015.

${ }^{14}$ Louis-José Barbançon, L'archipel des forçats. Histoire du bagne de Nouvelle-Calédonie (1863-1931), Villeneuve d'Asq, Presses universitaires du Septentrion, 2003, 447 p.

${ }^{15}$ See in particular : Jean Baronnet, Jean Chalou, Communards en Nouvelle-Calédonie et histoire de la déportation, Paris, Mercure de France, 1987, 431 p., Roger Pérennès, Déportés et forçats de la Commune, Nantes, Ouest éditions, 1991, 580 p., Germaine Mailhé, Déportation en Nouvelle-Calédonie des communards et des révoltés de la Grande Kabylie, 1872-1876, Paris, L'Harmattan, 1995, 423 p. Mélica Ouennoughi (dir.), Mémoires, histoire des déplacements forcés. Héritages et legs (XIXe-XXe siècles), Paris, L'Harmattan, 2014, 406 p., Rachid Sellal, Caledoun, terre de bagne des déportés algériens de Nouvelle-Calédonie, Alger, Casbah Editions, 2013, 157 p.

16 Odile Krakovitch, Les femmes bagnardes, Paris, Olivier Orban, 1990, 305 p.

17 Stephen A. Toth., "The Lords of discipline. The penal colony guards of New Caledonia and Guyana », Crime, Histoire et Sociétés, Vol 7, n², 2003, pp. 41-60.

${ }^{18}$ Isabelle Merle, Expériences coloniales. La Nouvelle-Calédonie (1853-1920), Paris, Belin, 1995, 479 p.

${ }^{19}$ Marine Coquet, La ville et le bagne. Histoire d'une commune pénitentiaire en terre coloniale, SaintLaurent-du-Maroni, Guyane, 1857-1949, Ph.D. thesis in History, Paris, Ecole des Hautes Etudes en Sciences Sociales, 2016, $660 \mathrm{p}$. 
considered separately. The study of the "bagnes era" in New Caledonia is marked by a dual assumption: on the one hand, that it was a secondary experiment, following the model for penal policies first orchestrated and tested in Guyana and reduced to a short parenthesis of thirty years of imperial history. On the other, that the bagne in New Caledonia "founded a line" whereas, paradoxically, almost a century of penal colonisation and more than 80000 convicts were not sufficient to root "penal settlers" in Guyanese soil. We shall see below that comparing the penal and colonial histories of these two territories of the French Empire entails calling into question these assertions. Once placed at the centre of the territories of which the system became part, the history of the colonial bagnes and the effects of their heritage in Guyana and New Caledonia proves to be simultaneously both similiar and markedly different.

In the first section, the paper will study the penal and legal commun basis of the transportation law of 1854, and in a second section address the choice of Guyana and New Caledonia as French penal colonies. In the third and fourth sections, it will explore practical penal experiences and local social fabrics in both colonies.

\section{I - One model, one law: THE ORIGINS AND FOUNDATIONS OF THE 1854 TRANSPORTATION ACT}

The French history of transportation during the nineteenth and twentieth centuries began in Guyana in 1852, was officialised with the voting of the 1854 Act, followed by New Caledonia in 1863.

This long-term policy driven by the Ministère de la Marine, had its roots in the earlier practices of sentencing convicted criminals to be oarsmen on war galleys or to hard labour, building ships in French naval dockyards, a frequent sentence for convicts during the seventeenth and eighteenth centuries. The end of the galley fleet in 1748 and the rise of the convict population in the Rochefort, Brest and Toulon shipyards during the French Revolution, was followed by the progressive modernisation of port facilities and maritime transport during the first part of the nineteenth century, which rendered this former system of punishment obsolete. This led to intense debate among penal specialists and in government circles about the necessity of penal reforms. ${ }^{20}$

The French revolutionaries were not unaware of the extraordinary experiment conducted since 1788 by the British in Australia where men, women and children were

${ }^{20}$ Jacque-Guy Petit et al., Histoire des galères, bagnes et prisons, XIIIe-XXe siècles, Bibliothèque historique Privat, Paris, 1991. Isabelle Merle, Expériences coloniales, op.cit. 
sentenced to temporary or permanent exile. ${ }^{21}$ Despite the loss of the American colonies in 1774, British penal policy had chosen to maintain its old tradition of convict transportation by transferring it to a new destination, a place almost unknown on the other side of the world. ${ }^{22}$ In the 1790s, under the Convention, French Guyana had been used; $_{\text {; }}$ as a place to exile political prisoners but the attempt failed .23 Sentences to deportation (for political prisoners) and to transportation (for common criminals) were included in the penal code of 1791 but were ultimately not implemented. The vast majority of French revolutionaries believed in the "ideal prison project" defended in Britain by the philosopher Jeremy Bentham. ${ }^{24}$ For them, the "new penal solution" had to be found within France, based on the building of new prisons using the principle of confinement in cells for criminals as a way of "regeneration". Philanthropists under the Restoration regime and the reign of Louis Philippe defended continued to defend this idea. In the 1840s, Alexis de Tocqueville spoke of his admiration for the Philadelphia penitentiary model. ${ }^{25}$

As the debate continued, "pro-transportation" supporters, including the Ministère de la Marine, tried hard to promote exile to penal colonies as a solution to the problem of criminality. British transportation to Australia was then seen as an example to follow and even surpass. The economic unrest and political uprisings of the 1840s increased the sense of insecurity and social fear among the ruling classes and made transportation a more and more realistic option. In the 1820s, the Ministère de la Marine had proposed several places which seemed suitable for founding penal colonies; the French West Indies, Guyana, Madagascar, Senegal, New Zealand and Australia. After the Second Revolution, the decree of 18 June 1848 sent insurgents to Algeria. The law of 9 February 1850 designated the Marquesas Islands, Mayotte and the Comoros as places of deportation for political prisoners, and New Caledonia was proposed for the first time. The decree of 27 March 1852 declared Guyana as a penal colony. New Caledonia was

\footnotetext{
${ }^{21}$ Colin Forster, France and Botany Bay. The Lure of a Penal Colony, Melbourne University Press, Melbourne, 1996.

22 Alan Atkinson, The Europeans in Australia, A History, Oxford University Press, Melbourne, 1998.

${ }^{23}$ Marine Coquet, La ville et le bagne, op. cit.

${ }^{24}$ Jeremy Bentham, The Works of Jeremy Bentham, vol. 4 (Panopticon, Constitution, Colonies, Codifications), edited by John Bowring, Edinburgh, 1838-1843 including Panopticon versus New South Wales: or, the Panopticon Penitentiary System, Compared.

${ }^{25}$ Gustave Beaumont, Alexis de Tocqueville, Du système pénitentiaire aux Etats-Unis et de son application en France, Paris, 1833.
} 
again suggested but was put on hold. Its future as a possible penal site constituted one of the objectives in taking possession of the territory on 24 September 1854.

Finally the French Transportation Act was passed on the 30 May 1854.

In opposition to the ideal prison model, the Transportation Act was meant to appear, in France, as a new and alternative system of exile. The idea was to make it better than the British penal system which at the time was being seriously questioned in both Britain and Australia. ${ }^{26}$ Evangelists and liberals saw the penal colony of Australia as a dreadful place undermined by violence which enabled the re-enactment of a form of white slavery. Free settlers and local Australian governments denounced the competition of cheap forced labour and the terrible reputation it bestowed their new country. Meanwhile British transportation was coming to an end. It was suspended in New South Wales in 1840, in Tasmania in 1853 and in Western Australia in 1868. During the same period, France debated and passed a law, thereafterinitiating its "own system" which pro-transportation leaders boasted was modern, efficient and humane.

As in the British case, the main objective of transportation was to rid the country of the worst criminals in order to protect 'honest people' against the former's "dreadful" influence. But unlike the British system which exiled men, women and often children with no age limit ${ }^{27}$ and for petty crimes in some cases, the French system, claiming to be more humane, limited transportation to male convicts from age 21 to 60 , sentenced for severe offenses (the majority concerning burglary with violence, attempted murder and murder, sexual assaults). ${ }^{28}$ Incarcerated women would also be given the opportunity to go but they were not to be forced to do so. On the other hand, French transportation aimed to be more efficient by ensuring that once transported, convicts would have little chance of eventually returning to France. This practice was called doublage:after their release, those sentenced to less than eight years had to remain in the colony-for the same length of time as their sentence. Though French transportation could not be applied to sentences of less than five years, even in this minimal case exile lasted at least ten years. Those sentenced to more than eight years, and they were the majority, were

${ }^{26}$ J-B. Hirst, Convict Society and its ennemies, London, Allen and Unwin, 1983.

27 A.G.L. Shaw, Convicts and the Colonies. A Study of Penal Transportation from Great Britain and Ireland to Australia and other parts of the British Empire, Melbourne University Press, Melbourne, 1966, 399 p., Stephen Nicholas (ed.), Convict Workers. Reinterpreting Australia's past, Cambridge University Press, Cambridge, 1988, $246 \mathrm{p}$.

${ }^{28}$ Attacks against private property constituted the first cause of condemnation to hard labor before attempted murders and murders, sexual assaults, arson and various kind of frauds. Isabelle Merle, Expériences coloniales..., op.cit., p. 125. 
condemned to perpetual exile with no chance of returning home unless they obtained a complete pardon. By contrast, in Australia, apart from those sentenced to life, convicts who in general were sentenced to seven or fourteen years were allowed to buy a return ticket when freed.

The aim of the French system was to use convicts as cheap forced labour for the "hardest tasks of colonisation": draining swamps, digging foundations, building roads, pipelines and colonial infrastructure. The objective was both economic and moral as it was supposed to organise - much more systematically than in the British case - the "Way of the Cross" to be followed by all convicts. They would begin their sentence by "hard work, suffering and penitence" and then, step by step, improve their situation until claiming the supreme reward foreseen in the 1854 law: access to a small landholding ${ }^{29}$. At the heart of the French transportation project lay the idea of building a new rural society based on small landholdings and families in order to give French outcasts a new chance in life. Unlike the British system, the 1854 law envisageda social utopia: the reconstitution in the penal colonies of French rural areas where both free and penal settlers would live side by side in harmony, unified and purified by the healthy activity of working the land. This was the ambition of the French advocates of transportation, keen to prove the efficiency of their system compared to both the prison model and the British transportation experiment. The latter were seen as disorganised and ill-prepared with no clear aims concerning the criminal's process of regeneration. In the promoters' minds, French transportation would offer land and a future to ex-convicts as well as to poor, honest French migrants, who were called upon to build together new societies in the Empire. Guyana and New Caledonia were chosen as the sites for this French social utopian experiment.

\section{II- THE CHOICE OF GUYANA AND NEW CALEDONIA AS PENAL COLONIES}

${ }^{29}$ Isabelle Merle, Expériences coloniales..., op.cit. 


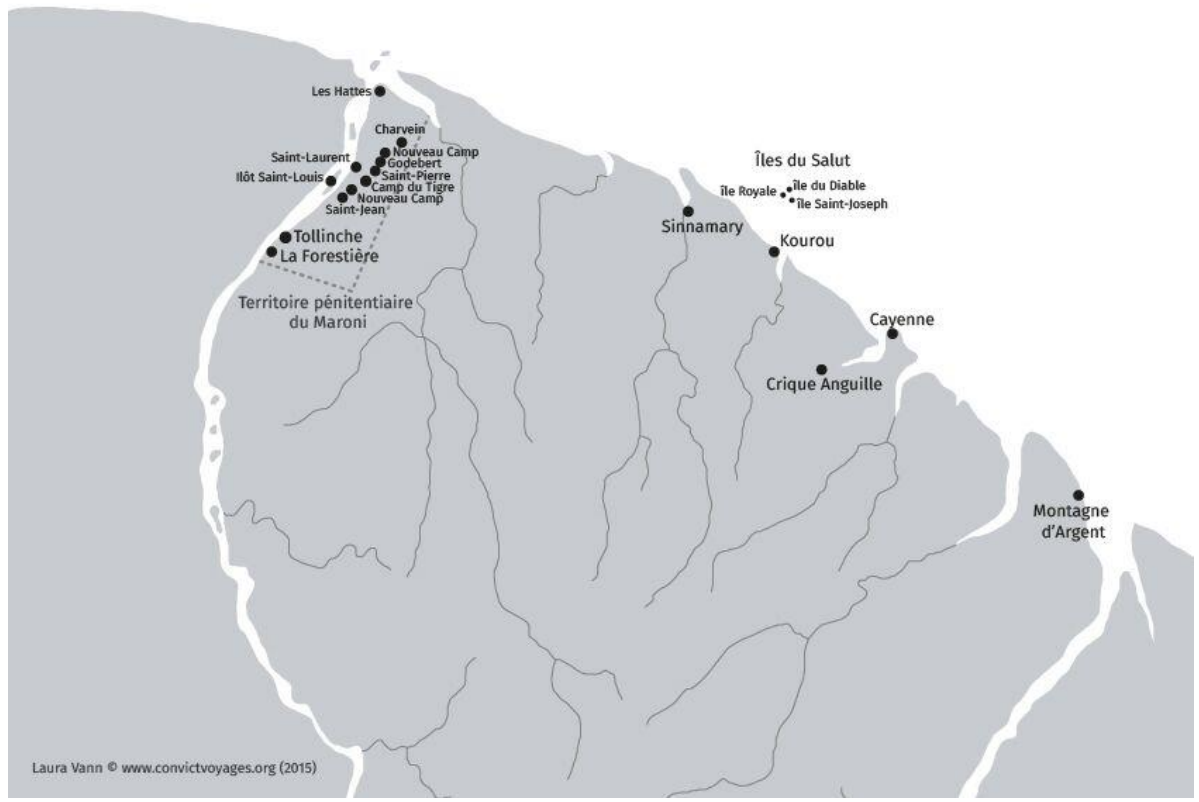

Fig. 1 : Map of penal camps in Guyana, author: Laura Vann ${ }^{30}$.

The frontiers of French Guyana were drawn up in 1713 by the Treaty of Utrecht which set the boundearies of a huge continental territory extending over more than 83,500 $\mathrm{km}^{2}$ between the Maroni and Opayock Rivers. Most of this territory was covered by equatorial forest where the majority of the local native population lived. Their presence has been attested there for about five thousand years. French colonial experiments started around Cayenne and a few military posts scattered along the coast. Several attempts at settlement were made, the first in Kourou in 1763 which is well-known for being a terrible failure. The surviving settlers found refuge off the coast on the Salvation islands and revealed how harsh living conditions were in Guyana: the exhausting struggle against a luxuriant natureal environment in a deadly, hot and humid climate exposed to tropical diseases. Nonetheless, at tahe end of the $18^{\text {th }}$ century the foundations of Cayenne and Kourou towns were built thanks to the introduction of indentured white labour from France and slaves imported from Africa. In the mid-19th

30 This map was produced as part of the research project led by Clare Anderson: Carceral Archipelago Project, School of History, University of Leicester (cf. http://convictvoyages.org/expert-essays/la-guyanefrancaise, checked in on September 03, 2017). 
century, on the eve of transportation, Guyana had only a thousand settlers for some 20,000 slaves, in addition to the native Indians partially decimated by the introduction of new diseases and the acts of runaway slaves (also called Marrons) hiding in the forests.

The decision in 1852 to open Guyana to transported French convicts was a new attempt to settle and develop this territory. Camps were first built around Cayenne in the East of the colony but the unexpected high mortality rate among wardens and prisoners owing to tropical diseases and bad living conditions made the efforts useless. Thus, a new plan to build camps on the banks of the Maroni River in the west of the territory, away from Cayenne and its free settler population, was launched. The idea was to reserve for transportation a large territory of 160,000 hectares, where convicts were to build the infrastructures of a new town, Saint Laurent-du-Maroni. Once freed, they would settle as farmers or craftsmen and be allowed to marry women from French prisons who were sent to Guyana on a voluntary basis. A family base would thus be reconstructed in accordance with the utopian social project of the 1854 act on transportation.

But the experiment was not successful. The first attempts at rural penal settlement in Guyana turned out to be extremely disappointing with a high mortality rate, an insufficient number of French women and spouses to balance the sex ratio and extreme poverty among the ex-convicts. As early as 1867, it was decided that convicts of European background, in other words "white convicts", would be sent preferably to New Caledonia, where a healthy climate and plentiful rich lands made the island apparently more apt to fulfil the expectations of transportation and its ideal new world of peasant farmers. Meanwhile, convicts from the Empire, and especially Algerians, were kept in Guyana on the pretext that they could cope much better with the deadly hot and humid climate of the place. But this was just a pretext to justify the fact that New Caledonia was supposed to be reserved only for "white convicts"and "white settlers". When the penal rural dream started to fade out in Guyana, the Algerian convicts were sent to New Caledonia under the new pretext that Guyana was too easy to escape from. 


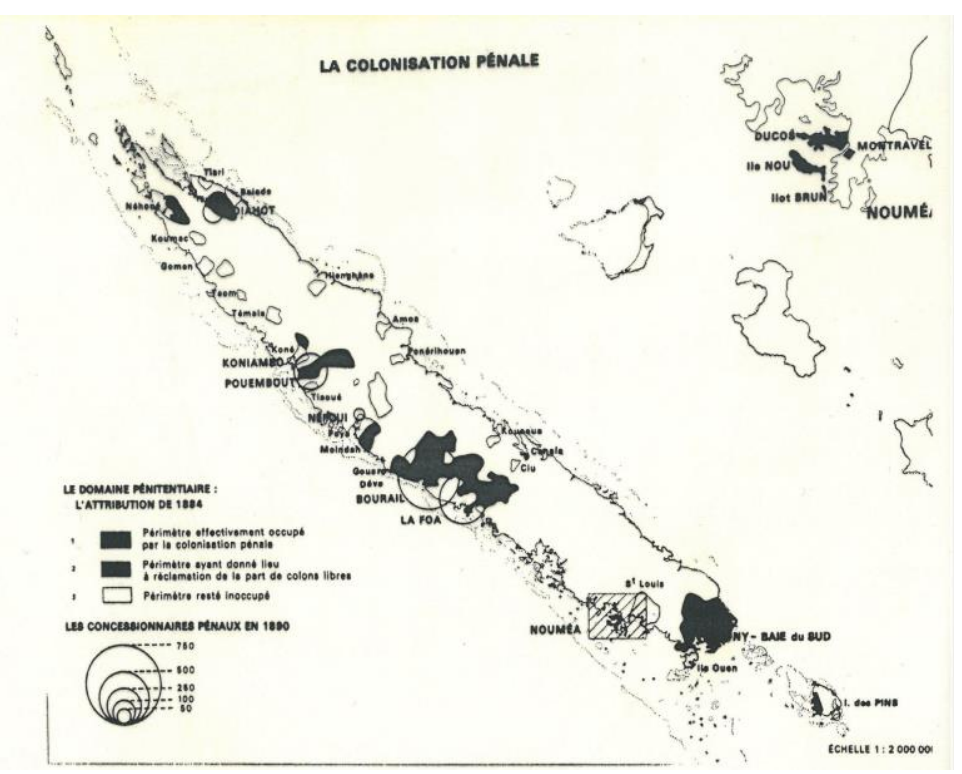

Fig.2: Land domain allocated to the penal colonisation in 1884. Atlas de la NouvelleCalédonie et dépendances, Editions de l’ORSTOM, Paris, 1981.

New Caledonia became French in 1853, ten years after the arrival of French Catholics from the Marist mission in Balade on the (North-East coast, on the same site where James Cook, the first European to visit the island, made a stop during a few days in 1774 followed by Bruny d'Entrecasteaux in 1793. Located in the central Pacific, 3,200 kilometres off Queensland coast of eastern Australia and $600 \mathrm{~km}$ south of the Vanuatu islands, New Caledonia is an island 400kilometres long and between fifty to seventy kilometres wide, crossed from north to south by a central mountain chain culminating at 1,600 metres at Mont Panie. Unlike Guyana, New Caledonia was relatively densely peopled with an estimated Kanak population of at least 50,000, cultivating rich alluvial lands rivers. As shown by the extent of Kanak organised in clans and/or chiefdoms, nevertheless, from the very start, the French colonial authorities preferred to ignore this local population. Instead, theyemphasised the richness and quality of the lands and the mildness of a healthy climate supposed to be similar to that of the Mediterranean-(in fact semi-tropical). These were the main arguments made as early as 1853 to promote New Caledonia as the land of settlement par excellence for French migrants looking for agricultural opportunities. The same were used to open the island to transportation in 
1863 and to receive "white" convicts sent from Guyana from 1867 onwards. Prisons were built on Nou Island, on the peninsula close to Noumea, while penal villages such as Bourail (1867) and La Foa (1871) were opened and land offered to well-behaved convicts.

However the French conquest of New Caledonia, far from being a simple matter, met with Kanak resistance and uprisings in many parts of the country. Between 1854 and 1880 , colonisation became a synonym for wars and land dispossession. In 1878, a major Kanak insurrection swept along the West coast and was savagely repressed, so that the entire region was almost emptied of its native population.- It was then that the principle of native reserves was reinforced in order to ultimately marginalise the Kanak and make place for settlers.

Following the failure of the insurrection, penal territories were enlarged in Bourail and La Foa and a new convict village created further north in Pouembout/Koniambo (1883). Convicts were settled on four hectares of land and some of them were lucky enough to see their wives and children arrive from France thanks to the help of the Ministère des colonies. In the 1870s and 80s, Therefore, New Caledonia became the symbol of the Transportation Act's rural ideal with ownership of small holdings and family reconstruction.

But, in 1887, things changed. With the passing of the Repeat Offenders Act (1885), which sentenced men and women convicted for consecutive petty crimes to transportation in a penal colony, Guyana was reopened for European convicts. Although short sentences were reserved for New Caledonia, Algerians with long-term sentences were also sent there. But in New Caledonia the development of penal colonisation came to compete with the ambitions of free colonisation. Transportation began to be contested, as it had been in Australia in the 1840s. The defenders of the anti-transportation movement found support in the appointment of Governor Paul Feuillet in 1894. The programme of this strongly convinced Republican was to "turn off the dirty water tap" and stop transportation as soon as possible. It gave priority to free colonisation and was intended to introduce a new settler population of 'dynamic honest small capitalists' ready to invest in the future of what Feillet called "little austral France".31 Through intense lobbying in Paris, he won the government over to his cause in 1897. Transportation was

${ }^{31}$ Isabelle Merle, Expériences coloniales..., op.cit., p. 278. 
definitively suspended in New Caledonia at the end of the nineteenth century and Guyana thus became the only French penal destination until its closure in 1938.

\begin{tabular}{|l|l|}
\hline Chronology & Penal colonies \\
\hline 1852 & Beginning of transportation to Guyana and first penal experiments \\
\hline 1853 & France takes possession of New Caledonia \\
\hline 1854 & French Transportation Act \\
\hline 1863 & Beginning of of transportation to New Caledonia \\
\hline 1867 & Failure of rural experiments in Guyana. « White » \\
\cline { 2 - 3 } & $\begin{array}{l}\text { convicts of French and European origins sent to New Caledonia while } \\
\text { « colonials », and especially Algerians, continue to be sent to Guyana. }\end{array}$ \\
\hline 1872 & Deportation Act (to New Caledonia) \\
\hline 1885 & Relegation Act (to Guyana and New Caledonia) \\
\hline 1887 & $\begin{array}{l}\text { Transportation of « White » convicts to Guyana resumed. Those with } \\
\text { short sentences sent preferably to New Caledonia. }\end{array}$ \\
\hline 1897 & Transportation to New Caledonia ends. \\
\hline 1938 & Repeal of Transportation Act in Guyana. \\
\hline
\end{tabular}

Fig.3: Time linepenal colonies.

The chronologies of Guyana and New Caledonia's penal history were to coincide several times between 1863 and 1897, the period during which the two colonies were simultaneously open to transportation. Both colonies received convicts transported under the 1854 Act but also political deportees from the 1848 revolution (in Guyana), relégués (repeat offenders) sentenced to transportation under the 1885 Act for repeated convictions for petty crimes.

In the colonial history of both countries, penal transportation constituted a crucial experience with long-term legacies. But the timescale and large scale effects were very different in the two cases. Transportation lasted only 34 years in New Caledonia (18631897) whereas it continued for more than 90 years in Guyana, from 1852 to 1938.

Between 1852 and 1938, more than a hundred thousand convicts were expelled from France and French colonies. Seventy per cent were sent to Guyana and thirty per cent to New Caledonia. 


\begin{tabular}{|l|c|c|}
\hline \multicolumn{1}{|c|}{} & $\begin{array}{c}\text { GUYANA } \\
1852-1938\end{array}$ & $\begin{array}{c}\text { NEW-CALEDONIA } \\
1863-1897\end{array}$ \\
\hline $\begin{array}{l}\text { Number of condamned (all } \\
\text { categories) }\end{array}$ & 80846 & 30000 \\
\hline $\begin{array}{l}\text { Convicts transported } \\
\text { (1854 Act) }\end{array}$ & & \\
& 57520 males (1852-1938) & 22000 males \\
& 315 females (1852-1907) & 224 females \\
& & $(1863-1897)$ \\
\hline Deported (1848 Act) & 329 (1848-1938) & 3928 (1872-1879) \\
\hline Recidivists (1885 Act) & 22 163 males & 3341 males \\
& 519 females & 455 females \\
& $(1887-1938)$ & \\
\hline
\end{tabular}

Fig.4 : Penal Statistics Guyana and New Caledonia.$^{32}$

Most of the convicts (54\%) sent to New Caledonia, arrived between 1863 and 1880 while $32 \%$ landed between 1880 and 1890 and only $14 \%$ between 1891 and $1894 .{ }^{33}$ In Guyana, $30 \%$ of the convicts sentenced under the 1854 Act were sent there during the early period (1852-1866) ${ }^{34}$ and more than $56 \%$ before 189735 .

The majority of these convicts were sentenced under the 1854 Act. Most of the political deportees from the Commune of Paris revolution in 1870 and the Kabyle insurrection in Algeria arrived in New Caledonia in 1872-1873 but left the colony in 1881 and 1895 when they obtained their pardon. Repeat offenders, few in number in New Caledonia, accounted for a significant proportion of the Guyana penal population from 1900 onward. A special camp was reserved for them in Saint-Jean beyond the territory of Saint-Laurent-du-Maroni, in the West of the country where convicts had been assembled at the end of the 19 th century ${ }^{36}$.

More than 45,000 convicts went to Guyana in the $19^{\text {th }}$ century over a period of 45 years and 30,000 to New Caledonia. Around 25,000 were sent to Guyana in the first part of the

32 From : Notices sur la transportation à la Guyane française et à la Nouvelle Calédonie, Paris (1852-1912), Notices de la déportation à la Nouvelle-Calédonie, Paris, (1872-1877), Sanchez Jean-Lucien, A perpertuité, Paris, Vendémiaires, 2013, Coquet Marine, La ville et le bagne..., op. cit., PhD thesis, EHESS, 2016.

${ }^{33}$ Isabelle Merle, Expériences coloniales..., op.cit., p. 118.

${ }^{34} \mathrm{ANOM}$, Notice de la Transportation à la Guyane française et à la Nouvelle-Calédonie pour les années 18661867, Paris, Imprimerie Nationale, 1868, p. 30.

35 ANOM, Notice de la transportation à la Guyane française et à la Nouvelle-Calédonie pour les années 18961899, vol. 1, Melun, Imprimerie administrative, 1902, p. 171.

36 Ibid. 
$20^{\text {th }}$ century, over a period of 40 years. ${ }^{37}$ The last convoy left France in December 1938 with repeat offenders on board ${ }^{38}$.

In the longue durée, French penal transportation is remembered as part of a distant history belonging to the $19^{\text {th }}$ century. However, in Guyana, it represents a long chapter covering the second half of the $19^{\text {th }}$ and first half of the $20^{\text {th }}$ century, formng an integral part of the territory's contemporary history.

\section{TWO TERRITORIES, A SIMILAR PENAL EXPERIENCE?}

The two penal colonies of Guyana and New Caledonia, successively and in different proportions, were the expression of the same colonial utopia embodied by the 1854 Act. The latter confined itself to general considerations and remained very vague about questions of practical organisation. Article 14 of the Act announced the imminent promulgation of a public administration regulation defining "everything concerning the execution of the present act and in particular $1^{\circ}-$ the disciplinary regulations of the establishments $2^{\circ}$ - the conditions under which land concessions, whether temporary or definitive, could be granted to convicts or ex-convicts, in view of the length of their sentences, their good behaviour, work and repentance [...] $»^{39}$. However the introduction of this legislation would take a long time.

Between 1852 and 1878, the governors and their prison services in each of the colonies were actually responsible for putting the 1854 Act into practice. The latter had to take into account the specificities of the local contexts confronting them, though on the whole they followed the same guiding principles.

These consisted in receiving the newly arrived convicts and putting them to work immediately "carrying out the hardest labour", as stipulated in article 2 of the 1854 Act. In the first ten years, the convicts landed in Guyana from 1852 onwards built wooden camps, to begin with on the Salvation Islands then on the mainland, at Cayenne where a small town already existed ${ }^{40}$ and on forestry sites on the Montagne d'Argent, at St

37 From a study of the Notices de la transportation à la Guyane française (1852-1912) and ANOM, H2039, H2040, H2041, H2042, H2043.

${ }^{38}$ Read more in Jean-Lucien Sanchez, A perpétuité, op. cit.

${ }^{39}$ Act of 30 May 1854.

40 Cayenne was founded in 1643. It was from this little settlement that France colonised Guyana. In the mid XIX'th century, there was a population of about 20,000 in Guyana, half of which lived in Cayenne and its neighbourhood. 
Georges and Kourou or on the Comté River. The village of Saint-Laurent-du-Maroni in the west of the territory, three hundred kilometres from Cayenne, was inaugurated in 1858. In 1860, the so-called prison territory (territoire pénitentiaire) of the Maroni, covering 160,000 hectares surrounding the village, was created and allocated exclusively to the management of transportation. In New Caledonia, when in 1864 the first convicts landed on Nou Island, not far from Noumea, they were immediately set to work on the site of a vast project to build permanent facilities for the penal colony's administration and accommodation.

As well as building the main and secondary prisons, the convicts were used for a great many tasks: building the cathedral, draining marshes, levelling Conneau hill, transporting water to Noumea, constructing buildings and barracks in Cayenne, on the islands and at Saint-Laurent, digging roads, doing forestry work, clearing land for agriculture and concessions, building huts etc. The intent was not only to use convict labour to assist colonial development but also to make the prison authorities autonomous and self-sufficient.

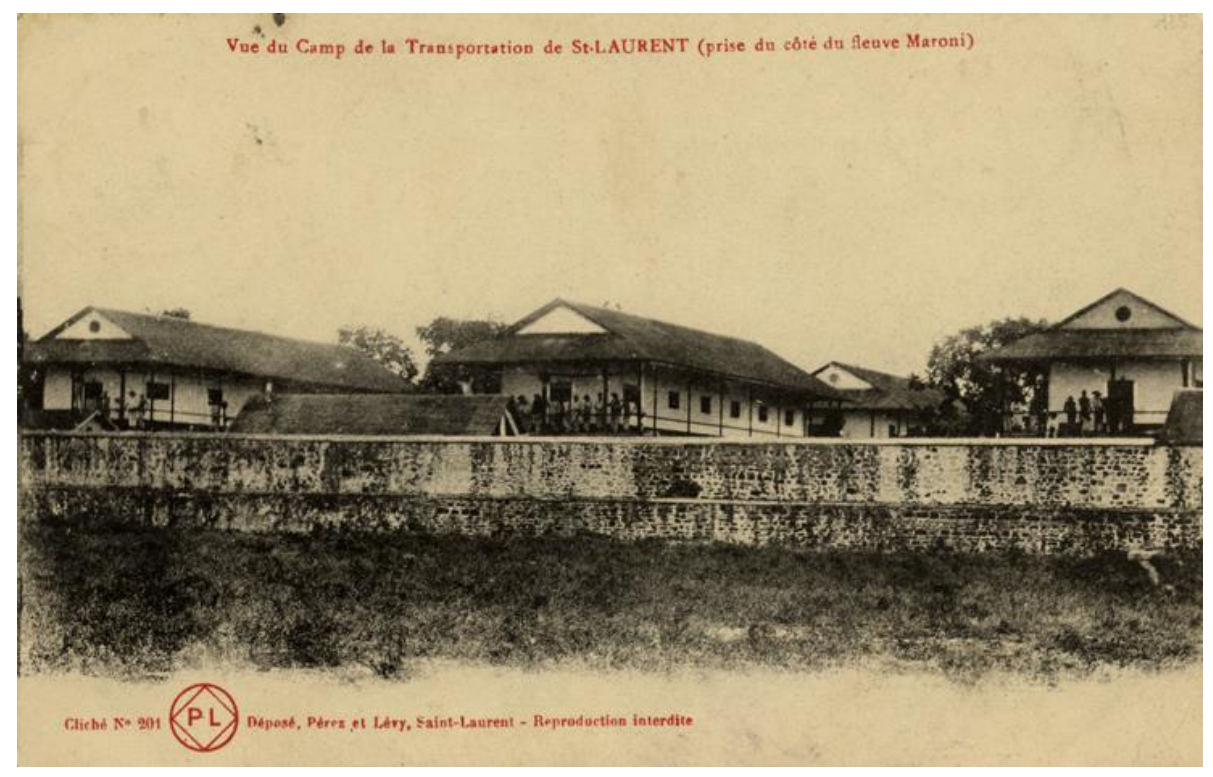


Fig.5 : camp of Saint-Laurent-du-Maroni, postcard by Perez \& Lévy, around $1910^{41}$.

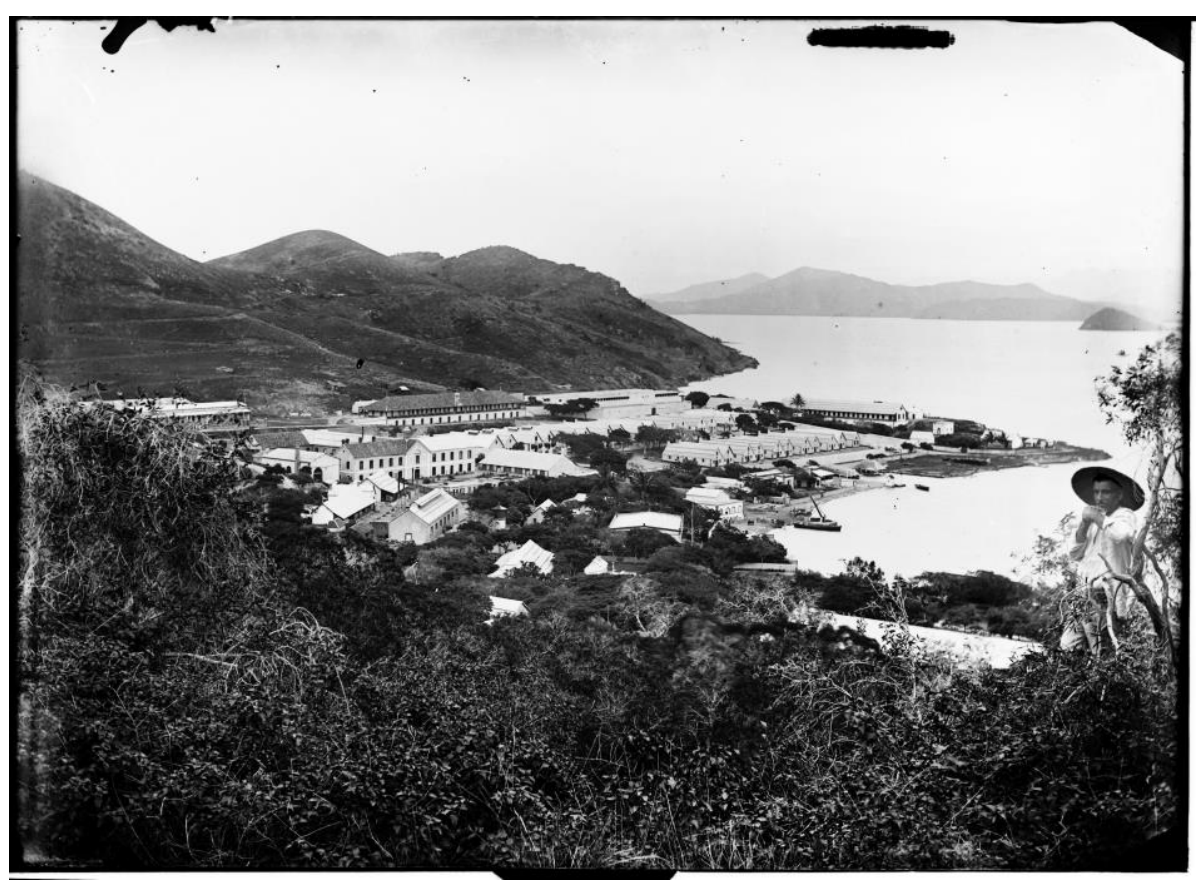

Fig 6: ANC collection Serge Kakou plaques de verre Anonyme 1900, 148 Fi 37 - 9, 13 x $18 \mathrm{~cm}$ [Nouméa, Ile Nou, vue d'ensemble du pénitencier.]

${ }^{41}$ ACSLM (Archives communales de Saint-Laurent-du-Maroni), CIAP (Centre d'Interprétation de l'Architecture et du Patrimoine) of Saint-Laurent-du-Maroni. 


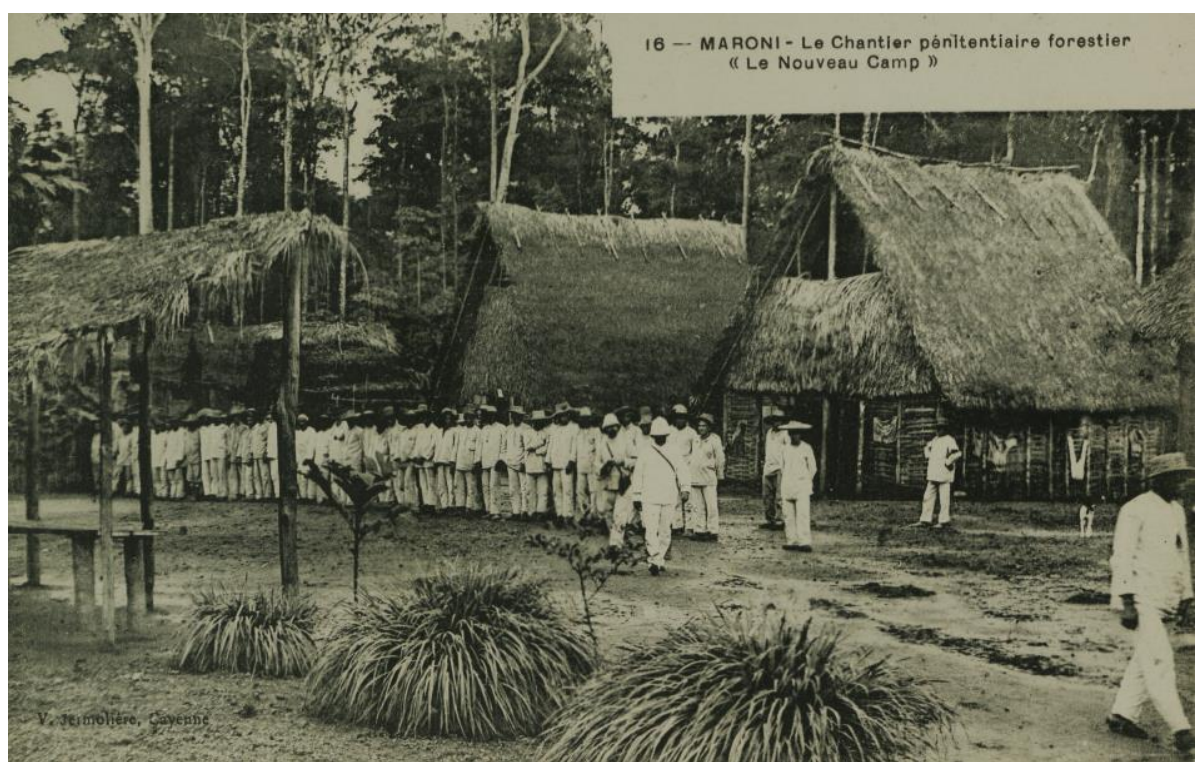

Fig.7 : forest camp named «Le Nouveau Camp», penal territory of the Maroni, date unknown ${ }^{42}$.

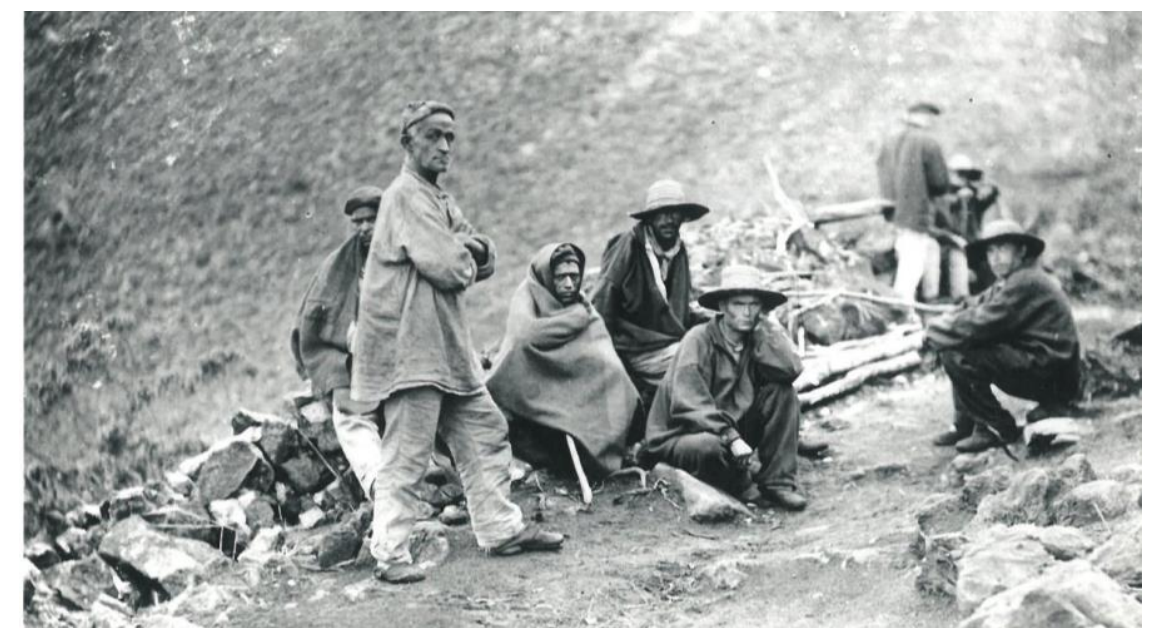

Fig.8: Groupe de forçats travaillant à la mine vers 1880, Nouvelle-Calédonie, collection Hughan, Musée de l'Homme.

${ }^{42}$ ACSLM, CIAP of Saint-Laurent-du-Maroni. 
In order to rationalise the way sentences were served and follow the injunctions of the 1854 Act, the Governor of New Caledonia took the early decision to divide the convict population into four classes ${ }^{43}$ according to the men's behaviour and conduct. The "rebels" and new arrivals made up the fourth class and performed "the hardest labour", as required by article 2 of the 1854 Act. Those best rated were to gradually rise to the first class and thus have the benefit of substantial advantages: the right to work for a wage (from $1869 \mathrm{on}^{44}$ ), to be assigned to private people (as servants or labourers ${ }^{45}$ ) and, above all, to be put on a land concession in a prison village such as Bourail (created in 1867), La Foa (1871) and Pouembout (1883) in New Caledonia and Kourou (1853), Saint-Laurent-du-Moroni (1857) or Saint-Maurice (1863) in Guyana.

It was not until 1880 that the Ministère de la Marine et des Colonies, responsible for the management of penal colonies, finally took the decision to publish the decree specifying how the law should be enforced concerning the disciplinary regulations to which all convicts in Guyana and New Caledonia should henceforth be subject. The decree of 18 June 1880 established a common system for grading convicts into 5 classes and abolished (in principle) corporal punishment ${ }^{46}$. This system, reduced to three classes in $1891^{47}$, made it possible to officially establish what the typical pathway of transportees should be.

As for the concessions system, it was eventually the subject of a decree on 31 August 1878 which clarified the modalities of attribution and transfer of land to convicts and ex-convicts ${ }^{48}$. During the 1880 s, there was an increase in the number of convicts settling in the penal villages allocated to them in New Caledonia. As in Guyana, in 1884 a vast prison territory of 110,000 hectares was reserved for penal colonisation in the region between La Foa and Bourail, largely emptied of its Kanak population by the repression of the 1878 insurrection. The Ministère launched appeals to the wives and families of

${ }^{43}$ The decision was taken on 25 January 1865 by the Governor of New Caledonia. Journal officiel de la Nouvelle-Calédonie, 1865.

44 These measures would be reasserted in the decree of 1880 which will be mentioned later. On the other hand, transportees' right to a wage, even low, was abolished by a decree in 1891 which revised the disciplinary system of transportation.

45 This measure recalls the "system" of Australian penal colonies where convicts could be found places as servants or farmworkers with private people.

${ }^{46} \mathrm{ANOM}$, Notice de la transportation à la Guyane française et à la Nouvelle Calédonie pour les années 18801881, Paris, Imprimerie Nationale, 1884.

${ }^{47} \mathrm{ANOM}$, Notice de la transportation à la Guyane française et à la Nouvelle Calédonie pour les années 18861895, Melun, Imprimerie administrative, 1900.

${ }^{48}$ Decree regulating the situation of transportees with land concessions in penal colonies, cited in the order of 23 January 1879, Journal officiel de la Nouvelle-Calédonie, 1879, p. 23. 
convicts to settle there in order to encourage family recomposition. Despite many failures, the prison authorities of New Caledonia managed to stabilise a small rural population inherited from the penal realm at Bourail, La Foa and Pouembout. According to the census of 1901, these villages respectively numbered 1,938, 1,486 and 482 inhabitants, which is not utterly negligible group out of a total white population of 12,253 of free origin and 10,506 of penal origin. Apart from Noumea,which had some 5,114 inhabitants of free origin, the prison villages and particularly Bourail, the territory's second "town", stood out as well-established European settlements.

At the same time, the number of penal concessionaires plummeted in Guyana where the very idea of penal colonisation seriously ran out of steam from the 1870s. The agricultural centre of Kourou was rapidly abandoned. Only the centre of Saint-Laurent and its surrounding areas (notably Saint-Maurice) remained, bolstered from the 1880s onwards by a free population attracted by the gold-digging sites opened high up the Maroni and Mana rivers. The sanitary problems, the rise in the number of convicts from 1887 onwards $^{49}$, and the tightening of discipline resulting from the decree of 4 September 1891 making access to the first class of convicts virtually impossible, all helped to make penal concessions scarcer. At the same time, they also significantly increased the number of convicts released from the camps withoutemployment, land or housing. This already central issue became crucial for Guyana in the 1890s, but it was no less the casefor New Caledonia where only $10 \%$ of transportees were to found concessions, owing to numerous failures and frequent abandonment of parcels of land.

At the turn of the century, the rise in the number of vagrant ex-convicts became an acutel social problem for both colonies. In New Caledonia, it weighed on the decision to suspend transportation in 1897. The disappointing results of penal colonisation experiments, along with the social problems created by the growth of an ex-convict population obliged to live in the country, caused the rural utopia aspects of the 1854 Act to be abandoned. In Guyana, this resulted in harsher imprisonment conditions: the bagnes carceral ideology supplanted the colonial aspect of the initial project, recalling the very similar stages experienced by the Australian "system" whose punitive turn in the 1820-1830s had triggered the abandonment of transportation from the 1840 s onwards.

${ }^{49}$ In particular, due to the voting of the law on the relegation of repeat offenders (1885 Act), with the first convoys arriving in Guyana in 1887, and the resumption of convoys of European convicts in Guyana from 1887 onwards (cf. supra) 


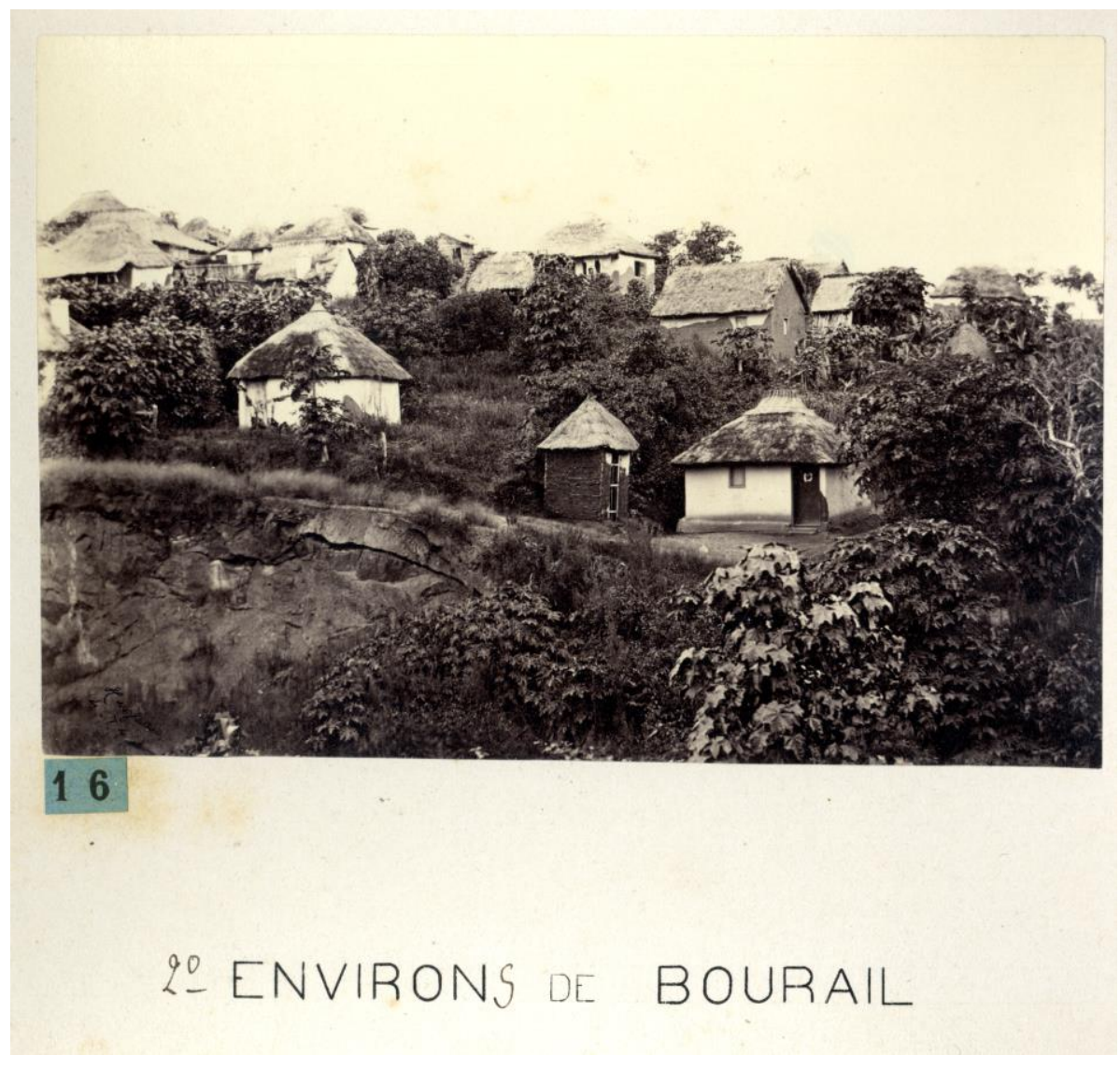

Fig.9 : Archives de la Nouvelle-Calédonie, album administration pénitentiaire 1, 193 Fi 16, 10,8 x 15,5 cm, Allan Hughan. "Environs de Bourail. 1874 


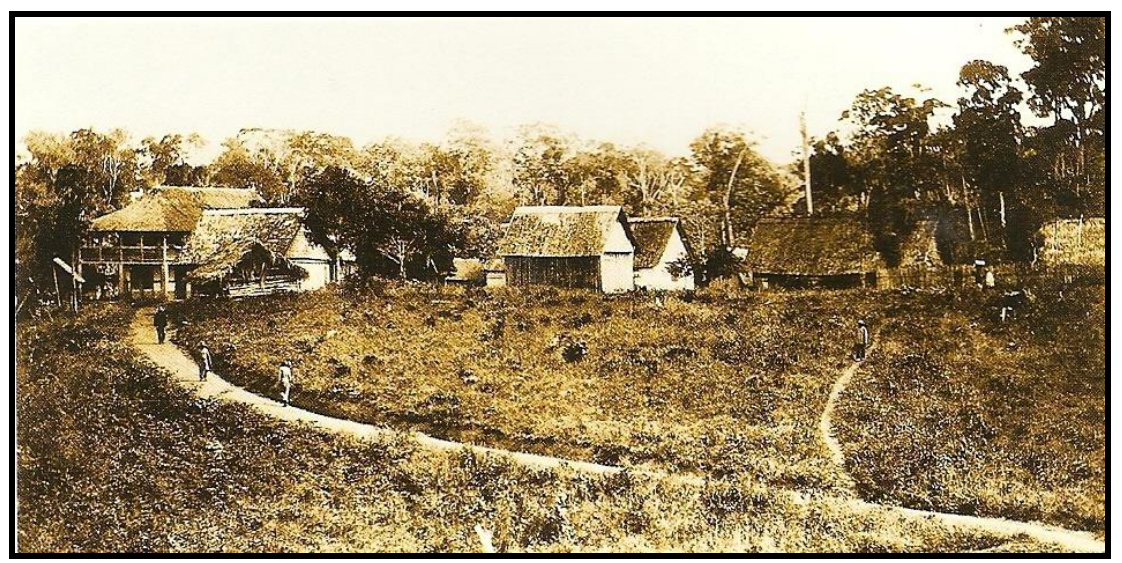

Fig.10 : camp of Saint Maurice, near to Saint-Laurent-du-Maroni, Guyana ${ }^{50}$.

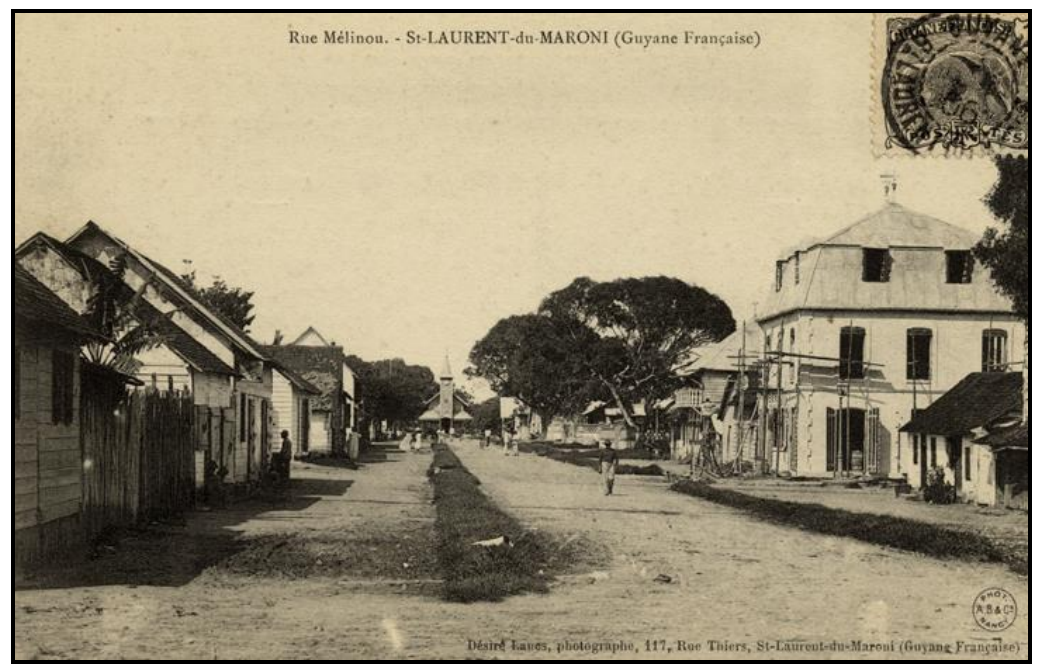

Fig.11 : a road in Saint Laurent du Maroni, Guyana. Postcard of Desiré Lanes, around $1910^{51}$.

\section{IV - NEW CALEDONIA AND GUYANA: TWO DIFFERENT SOCIAL FABRICS}

In both Guyana and New Caledonia, prison authorities were accused of being a "state within a state", acting with a great deal of autonomy and exercising considerable influence as governors competed with the civil administration's departments and

${ }^{50}$ ACSLM, CIAP of Saint-Laurent-du-Maroni.

${ }^{51}$ ACSLM, CIAP of Saint-Laurent-du-Maroni. 
representatives of colonisation. Upon the arrival of the first convoys, the representatives of Guyanese free colonisation ${ }^{52}$ wrote petitions contesting the presence of convicts in the town of Cayenne. Subseuqnelty, the debate was reopened by the Chamber of Commerce and Industry and the General Council in the 1870s. Tensions ran so high that in 1878, a Direction de l'administration pénitentiaire (Department of Prisons), no longer under the authority of the Governor of Guyana, was created by decree $^{53}$. In 1899, the prison authorities' headquarters were moved from Cayenne to Saint-Laurent-du-Maroni. In New Caledonia, during the administrative reforms in 1874, the governor emphasised the exceptional character of this country which intended to receive transportees and political deportees. The latter were to be placed under the same prison authority which would be given a special status. The governor stated that this would be "to make the director of prison services an administrative head with the same access to the Conseil privé as those of other services[...] $]^{54 " . ~ " F o r ~ t h e ~ D i r e c t o r ~ o f ~}$ Prison Authorities' extremely broad responsibilities mean that he holds a central position in the organigramme reflecting the power of his institution. The prison authorities [...] must seek the assistance of all the colony's administrative heads; most of the latter may have need of them ${ }^{55}$. He added that "It may be said that, for the present, in view of their relative importance, [they] Sare directly and indirectly concerned by most of the important questions arising in the colony ${ }^{56 "}$

Indeed, the bagne played a central role in the colonial economy as a consumer and producer of goods. It was by far the greatest provider of labour for Caledonian and Guyanese public authorities, private individuals and local firms, allocating convicts to public works, placing them as servants with free settlers or hiring them out to the mines in New Caledonia or the forestry industries in Guyana. In both cases, it directly managed

\footnotetext{
52 Like other "old" colonies, such as Guadeloupe, Martinique or Reunion Island, Guyana had a Conseil Général elected by free settlers since 1828, a form of political representation which would serve as a model during discussions on the creation of a Conseil Général in New Caledonia in 1885.

${ }^{53}$ By decree 16 February 1878: ANOM, Notice de la transportation à la Guyane française et à la NouvelleCalédonie pour les années 1878-1879, Paris, Imprimerie Nationale, 1883.

${ }^{54}$ Report from the Governor of New Caledonia to the President of the Republic, 12 December 1874. Appendix 1 of the order promulgating the organic decree of 12 December 1874 concerning the government of New Caledonia, Journal Officiel de la Nouvelle-Calédonie, 1 March 1875, p. 112-117. 55 Ibidem, p. 117.

${ }^{56}$ Ibid. In his report of 12 December 1874, the Governor specifies : "in order to avoid any conflicts with other services, I have endeavoured to define the attributions of this civil servant [the director of the prison authorities] in such a way as to create a form of autonomy for him, while maintaining close links between him to his colleagues".
} 
an large amount of property and land reserved for it. In New Caledonia, this gave rise to a very conflictual debate in the first sitting in 1885 of the elected Conseil général. In Guyana, the unique status of Commune pénitentiaire (prison Commune) was specially created for Saint-Laurent-du-Maroni in 188057: from then on, the village was run by a municipal committee exclusively composed of members appointed from among the prison staff58. Closely associating local and prison authorities, this special status was meant to make it possible to "provide ex-convicts with the means of subsistance and rehabilitation"59. It thus made the town the sole usufructuary of the 160,000 hectares composing the Maroni territory and granted it large budgetary advantages to ensure the success of its mission ${ }^{60}$. The adoption of this decree sparked off heated debates in the Conseil général of Giana. In 1901, the governor himself, Albert Grodet, took sides:

"Would it be a acceptable for the Colony, which due to Transportation and Relegation has seen an increase in budgetary responsibilities and gained an extremely undesirable reputation, to also make sacrifices in order to allow the prison town to be able to provide work for the gentlemen released ${ }^{61}$

Tensions came to an end at the turn of the century, when it was finally decided that the overwhelming majority of convicts would serve their sentence on the Moroni prison territory. In the East, at Cayenne and Kourou, smaller camps were maintained, above all to use penal labour for the towns' upkeep. These conflicts between a civil elite and representatives of the prison authorities were the expression of a crucial isssue in the

${ }^{57}$ By decree on 16 March 1880: ANOM, Notice de la transportation et de la relégation à la Guyane et à la Nouvelle-Calédonie pour les années 1880-1881, Paris, Imprimerie Nationale, 1884.

58 Members of the Maroni municipal committee were not elected therefore but appointed by the Governor on recommendation of the director of the prison authorities. Thus very close complicity was established between the town and the prison authorities. For example, the president of the Maroni municipal committee, who took the title of Mayor of the town, acted simultaneously as commander of the camp of Saint-Laurent-du-Maroni and its subsidiary camps and as assistant director of the prison authorities. In reality, relations between local s and prison authorities were sometimes conflictual but it is undeniable that the 1880 decree actually made Saint-Laurent a "necessary branch of the prison authorities"

(expression taken from : ANOM, H2022, annotation by the director of the prison authorities to the report of the assistant inspector of the Colonies on 15 January 1924. The possibility of establishing such a system was never discussed in New Caledonia.

${ }^{59}$ ANOM, H2022, report by the inspector of Colonies, April 1901.

60 These included in particular exoneration from the taxes which the other Guyanese municipalities owed the colony's government since the adoption of the 15 October decree (notably on the revenue from the sugar mill at Saint-Maurice, to be paid by the Moroni prison town). For more details, see Marine Coquet, La ville et le bagne..., op.cit. p. 190-197.

${ }^{61}$ ANOM, H2022, annotations by the Governor of French Guyana to the report of $3^{\text {rd }}$ class inspector of colonies Ferlande, concerning the investigation of the service of M. Barre, mayor of Saint-Laurent-duMoroni. 
two colonies: competition between free and penal colonisation. In both, it was a question of "containing" the penal institution to prevent it completely overrunning the physical, political and human space of the Guyanese and Caledonian universes. In this respect, it should not be forgotten that the colonies of Guyana and New Caledonia were not only penal colonies. Other populations lived there: free settlers, traders, from France or Europe, autochthonous or indigenous populations, Kanak, Amerindians, Noir Marrons of Guyana and "coloured" immigrants, Javanese, Tonkinese, Japanese imported to New Caledonia, Indian and Chinese "coolies" brought to Guyana ${ }^{62}$ and migrants from the Caribbean zone in Guyana.

How was coexistence of the free and the penal worlds to be organized? That was the structural question facing these two societies marked by a division of their own. For, in the French colonial empire, it was only in Guyana and New Caledonia that a social and political project containing this dichotomy between "free" and "penal" was supported. This crept into everyday language, through the use of a specific terminology - "free settlers", "penal settlers", "concessionaires" - "ex-convicts" associated with that of the categories linked to the sentence such as " political deportees", recidivistes (repeat offenders) or "transportees". Equivalents would be found in the penal worlds of the anglophone Pacific - Australia and Tasmania63.

In Guyana as in New Caledonia, from the very start there was a very strong desire among the representatives of the free population to distinguish themselves from the penal population. In Guyana in 1852, a ministerial dispatch attempted to reassure free settlers that future prisons would be confined to isolated spaces far from free settlements ${ }^{64}$.

The governors themselves were convinced of the necessity of strictly defining the prison authorities' remit and of maintaining aswatertight as possible theborder between free and penal populations. The prison authorities' directors subscribed to the idea of separate administration in order to better control their territories. All agreed on favouring a policy of segregation between the penal and free populations. In New Caledonia, other systems of segregation were working very efficiently and, in particular, the principle of native reserves which grouped together the Kanak in specific places

\footnotetext{
62 Imported thanks to economic agreements made between France and Great Britain.

${ }^{63}$ Let us mention here the ambitious project of Clare Anderson entitled "Carceral Archipelago" which aims to study the penal worlds from the perspective of a connected history and in the very long term.

${ }^{64}$ For a more in-depth study of relations between Cayenne and Saint-Laurent-du-Moroni in the years from 1850 to 1900, see Marine Coquet, La ville et le bagne..., op. cit., p. 198-207.
} 
where settlers did not have the right to live. But the question of segregation between free and penal populations also played an important part in public debate at the end of the XIX ${ }^{\text {th }}$ century and remained a constant concern in Guyana up until the Second World War.

In the very first instance, as we have seen above, it was a question of segregating territorial spaces by pushing convicts as far west as possible in Guyana and by reserving places for concessions in New Caledonia. Ex-convicts were banned from living in Noumea and Cayenne - unless they had found work - respectively in 1865 and 1876. Those who had no access to a land concession were meant to look for means of subsistance themselves, "in the bush" in New Caledonia or in Saint-Laurent-du-Moroni, Kourou or elsewhere in Guyana. It became compulsory for all ex-convicts not living in Nou Island prisonor a prison territory to carry a permit. 65 In 1880, ex-convicts were banned from living in any of the inland centres. The plan of Saint Laurent village also bears witness to borders between the "free" and the "penal" populations on a much subtler scale. From the very beginning, the town was organised into carefully reserved neighbourhoods, whether they were the so-called 'official district' (for the prison authorities officials), the so-called 'colonial district' initially built for the settlement of penal concessionaires (figure X). In illness as in death, segregation was omnipresent: special buildings and part of the cemetery were reserved for the penal population, others for the free population.

\footnotetext{
${ }^{65}$ By Arrêté, December 28th 1875.
} 


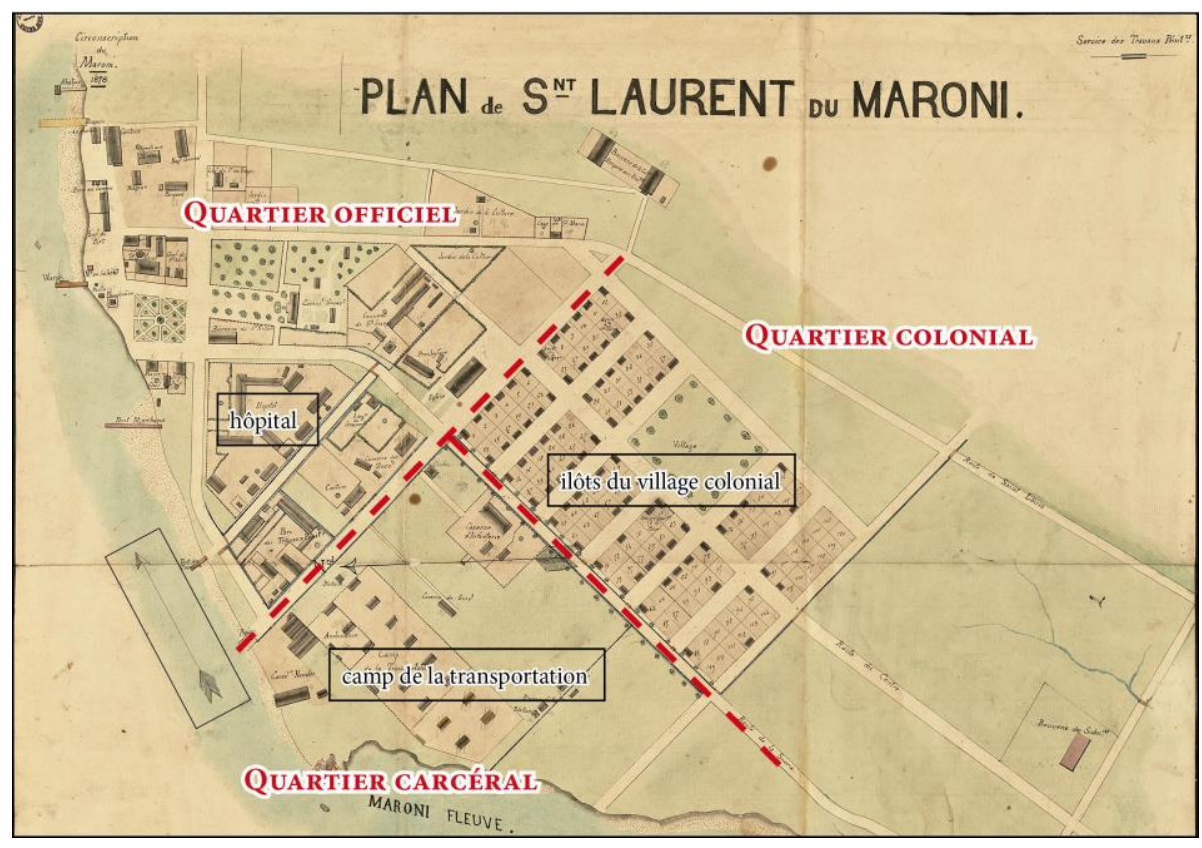

Fig.12 : annotated map of the town of Saint-Laurent-du-Maroni, $1878^{66}$.

But the desiderata of the colonial authorities and the repeated efforts by the prison authorities in the two territories to perfect a model of a strictly organised society on both sides of a border separating the free from the penal population were, to a great extent, contradicted by social practices, human relationships and interdependences between sites and their populations.

When the first free settlers arrived in Saint-Laurent-du-Moroni at the turn of the century, they bought the land concessions of ex-convicts in the centre of the colonial district and the latter were driven out into decrepit huts in streets on the outskirts of the town. These streets unofficially became "the ex-convict district". From then on, the "composition of the town"67 no longer depended solely on the local or prison authorities but was in fact a constantly readjusted compromise resulting from the inhabitants'

${ }^{66}$ From ANOM, 1TP470.

${ }^{67}$ Isabelle Backouche, Nathalie Montel, "La fabrique ordinaire de la ville", in Histoire urbaine, $\mathrm{n}^{\circ} 19$. 2007/2, pp. 5-9. 
social practices. This can be seen in the case of the "Chinese village" which developed and spread spontaneously in Saint-Laurent-du-Moroni around "Annamite" penal concessionaires and free Chinese migrants ${ }^{68}$.

In both New Caledonia and Guyana, ex-convicts eked out a living in "the bush" or "the forest", thanks to mine work, jobs settlers could offer them and the reception they managed to find among the indigenous population or their former penal colony companions who had become concessionaires. The colonial authorities were particularly concerned about "vagrancy". In New Caledonia between 1864 and 1879, 165 ex-convicts benefited from a curious measure provided for in article 6 of the 1854 Act which authorised their departure to neighbouring colonies in the event of an economic crisis or unemployment ${ }^{69}$. At the end of the century, a member of the Conseil Général proposed the creation of an immense reserve in the New Hebrides ${ }^{70}$. In the territory, there was an increase in checks and ex-convicts were forbidden to move around freely in the native reserves and entering the centres of free colonisation.

However, in reality, few of these regulations had any practical effect. Ex-convicts had no choice but to "roam" in search of a means of subsistence, disregarding the police and road? Identity? checks. Paradoxically, they were in fact the only ones in this colony to allow themselves this liberty. The free and penal settlers were tethered to their farmwork and land concessions while the Kanak, watched over by their chiefs, could not move from their district without permission. Though the ex-convicts, in contact with local tribes, may have left children behind, they left no official descendants and very few traces of their fate. On the other hand, the penal experiment in New Caledonia gave rise to firmly rooted penal villages in which the population kept to itself and for a long while bore the stigma of the bagne. Up until the 1950s, in families of free origin there was no question of marrying girls or boys to descendants of chapeaux de paille (straw hats) ${ }^{71}$. And the authorities themselves were concerned about the second generation: for instance, some children with a penal background from Bourail or La Foa were placed in

${ }^{68}$ Made up originally of a few huts belonging to penal concessionaires termed "Annamites", from the Indochinese colonies, the district called the "Chinese village" spread during the XIXth century. Chinese migrants came and settled there. Ex-convicts of all origins lived there or went there regularly. A quay was built and its alleyways attracted a large population of convicts, gold-diggers, traders, landladies, etc. It completely escaped the authorities' control, despite the latters' efforts to limit its expansion and the frequently illegal practices that went on there. See Marine Coquet, La ville et le bagne..., op. cit., pp. 281293.

${ }^{69}$ Isabelle Merle, Expériences coloniales, op.cit., p. 196.

70 Ibidem, p. 222.

${ }^{71}$ Nickname given to the descendants of convicts. 
boarding schools at Nemeara or Fonwhary at the earliest possible age in order to remove them from their home environment. Finally, up until the Second World War the leading families of Noumea controlling the Conseil Général would never have allowed one of theirs to be tainted by this past which they long sought to keep silent and to repress.

Similarly in Guyana and especially in the territory of the Maroni prison town, the administrative authorities' methods of categorising the population as "free" or "penal" were both efficient while being contradicted by social practices. Numerous examples in the everyday life of Saint-Laurent bear witness to this. The free and penal populations did not visit the same cafes and restaurants or sit in the same rows at the cinema ${ }^{72}$. Nonetheless, in the street and market, in some buildings or with some employers, free and penal inhabitants ran into and shouted abuse at each other, or made friends and helped each other. Many male and female workers on the gold-digging sites shared similar living conditions with ex-transportees and, at times, faced them together. Such was the case for immigrant women from the Caribbean zone who established relationships with ex-convicts and founded families. The organisation of the 14 July and 11 November festivities in the municipality of Saint-Laurent are revealing examples of the ambiguities created at village level by this distinction between the free and penal worlds. While in metropolitan France, these were annual occasions aimed at unifying the nation around common memories, the national festivals at Saint-Laurent-du-Moroni were an opportunity for the authorities to test this distinction ${ }^{73}$. The programme for the 14 July 1934 festivities (see figure 13) testifies to the organisation of different activities for the "penal element" and the "free element", differentiated by the kind of activity, where they took place and even the prize to which the winners were entitled.

\footnotetext{
${ }^{72}$ Marine Coquet, La ville et le bagne..., op.cit., pp. 366-370.

${ }^{73}$ It should be noted that the same festivities organised by the town of Cayenne do not appear to have given rise to the same display of segregation between the free and penal populations: see in particular Denis Voituret "Représentation des sociabilités sportives dans les colonies de la Guyane française (18901912), Outre-mer, revue d'histoire, vol. 96, nos 364-365, 2009, pp. 17-35.
} 


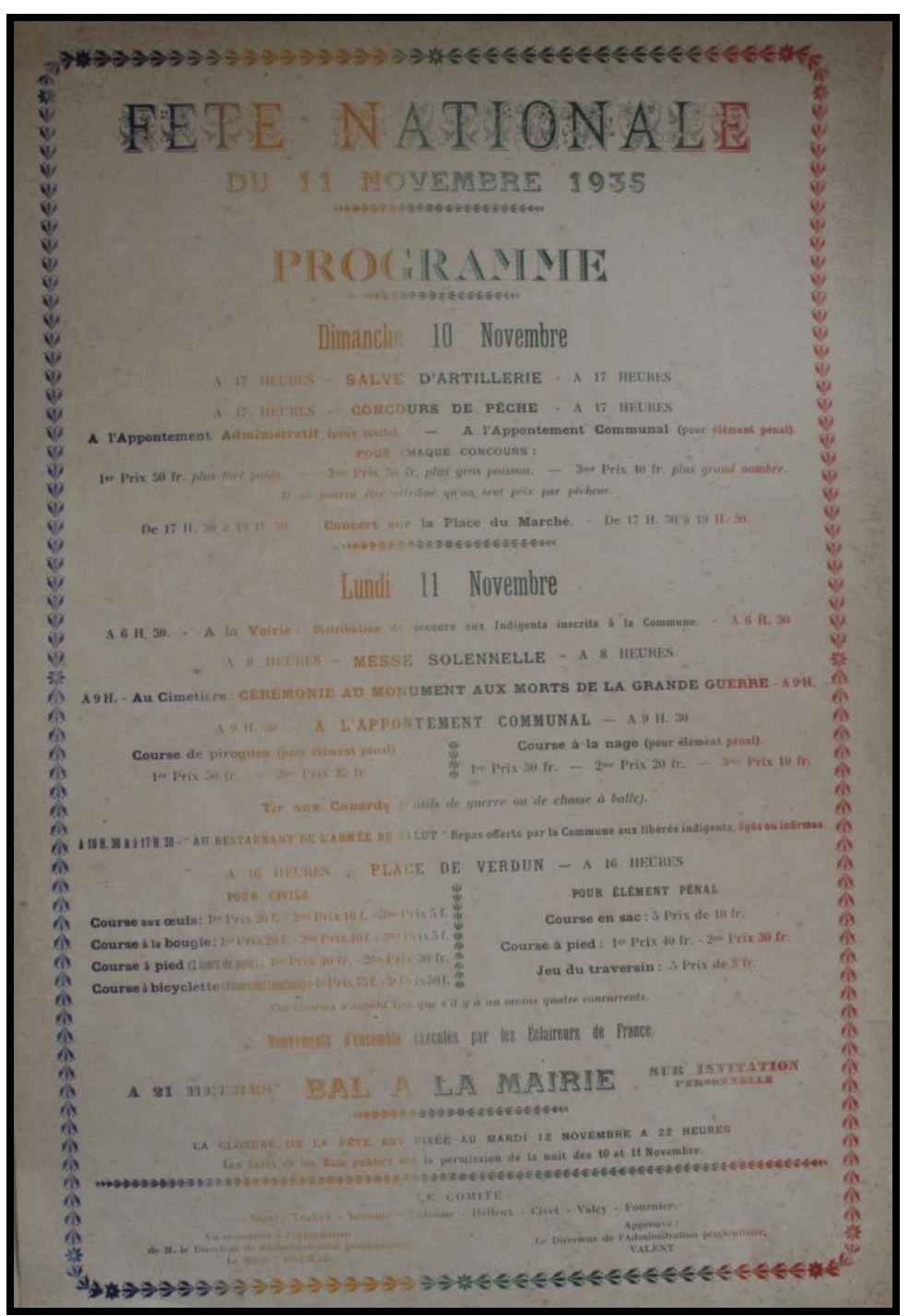

Fig.13 : program of the ceremony of 11 November 1935 in Saint-Laurent-du-Maroni ${ }^{74}$.

On these occcasions, little stalls were set up all around the market place and rented out to inhabitants to sell food and drinks. Some were reserved for free traders, others for penal ones. When, on 22 November 1922, Hortense, an immigrant from Martinique married to Athman, a Tunisian ex-convict, claimed the right to set up her stall among the

${ }^{74}$ ACSLM, 1I Fêtes publiques. 
free traders, her request was refused. According to the mayor, there was "a certain demeaning quality as she had consented to marry an individual of penal origin"75. Tainted by stigma of the bagne borne by her husband, Hortense was on the fringe of the free population. Far from being a unique case, the couple formed by Hortense and Athman and the authorities' reaction to their union, show how the borders between the free and penal world were both formative and porous, even at the heart of the Maroni penal territory in Guyana's "penal colony capital".

\section{Conclusions.}

On opposite sides of the world from each other, the colonies of Guyana and New Caledonia were profoundly marked by the imposition of bagnes and the social and rural utopia aspect of the 1854 transportation Act. Whereas the experiment lasted just 35 years in New Caledonia and was part of a history associated with the $19^{\text {th }}$ century, it continued in Guyana for almost a hundred years and only really came to an end with the departure of the last transportees in 1953. Guyana's long penal history thus forms an integral part of the $20^{\text {th }}$ century.

However, in the two cases, memories of this penal past are currently used in a very different fashion. In New Caledonia, penal colonisation "produced descendants", to coin a phrase. These were families resulting from its particular penal history, from villages like Bourail, La Foa or Pouembout whose very names betray a filiation long considered shameful. In the families also stigmatised by their name as descendants of "straw hats", silence was the order of the day so that the grandfather's "stain" would be forgotten or erased. Louis José Barbançon has testified to the weight of what was left unsaid ${ }^{76}$. Paradoxically, it was in the 1980s, under the pressure of local events and Kanak demands for independence, that penal memory seems to have been unlocked. This was probably due to to the famous speech by the Kanak leader Jean-Marie Tjibaou, at Nainville les Roches in 1981, who affirmed the legitimacy of "the victims of history's" presence in the country. ${ }^{77}$ First and foremost among the latter, were those whose

75 Marine Coquet, La ville et le bagne..., op.cit., pp. 362-363.

${ }^{76}$ Louis José Barbançon, Le pays du non dit. Regards sur la Nouvelle-Calédonie. Noumea, 1992, 133p.

${ }^{77}$ It should be noted that for Jean-Marie Tjibaou the notion of "victims of history" did not concern the

Kanak but all those who had been driven or forced to settle in New Caledonia in the XIX and XX ${ }^{\text {th }}$ centuries. From the Kanak point of view, it was a question of recognising and accepting the legitimacy of their presence in the country. Nanville les Roches round table, 8 July 1981. 
descendants had arrived in shackles. The families descended from convicts began to reveal their genealogy in the 1990s and a heritage interest in protecting the buildings and ruins which up until then had been neglected began to develop. Representatives of the "penal community" sought to find out more about the convicts' history, including that of the Algerians transported and deported there. This was well illustrated by the Calédoun exhibition which took place at the Institut du Monde Arabe in Paris in 2011. Today this kind of action is part of those termed 'non-Kanak' in the broader dynamics of asserting separate and rival community memories, for example of convicts, the Vietnamese settlers? and natives of Réunion Island.

But this revival of memory and especially that concerning descendants of convicts found no echo in France where the New Caledonian bagne had been largely forgotten. The bagne imagery had long been associated with Guyana, and not with its New Caledonian counterpart In Guyana, once the last convicts had left, the camps were abandoned, the archives sent back to France and the history of the bagnes and convicts reduced to an outgrowth of French metropolitan history. It was replaced, in the 1980s, by studies devoted to Guyana's Creole population, the descendants of former slaves emancipated since $1848^{78}$. As the sociologist Marie-José Jolivet has explained, as far back as the $20^{\text {th }}$ century postcards portrayed an "image separated into different categories: the bagne, colonial life, the natural environment, the exotic populations". This iconography thus presented just as many "reductions" of the colony, according to Jolivet who notes that at the time "a more global view never seemed conceivable"79. Once the bagne was gone, the 'reduction' of Guyana to its Creole element, marked by the history and memory of slavery, replaced that of the bagne. Recent migratory flows (Surinamese, Brazilians, Hmongs and Haitians in particular) as well as the visibility claimed by the Marrons and Amerindians, have today made the problems of defining Guyanese identity more complex, by to a certain extent overshadowing the penal past. Unlike in New Caledonia, here there were no descendants to claim such a bond with the bagne. Quite the opposite, in Saint-Laurent-du-Moroni, for a long while defined by its 'rumours' 80 , some inhabitants tried to confine strictly memory of the penal colony to the prison camp :

${ }_{78}$ Serge Mam-Lam-Fouck, La Guyane française de la colonisation à la départementalisation. La formation de la société créole guyanaise, Fort-de-France, Désormeaux, 1982, 188 p.

${ }^{79}$ Marie-José Jolivet "Image de Guyane entre réduction et cloisonnement", in Autrepart, n²4, 2002, pp. 107-124. See also, by the same author, « Mémoires guyanaises. Fluctuation des représentations créoles du passé », in Guillaume Pierre (dir), Identité caraïbes, Paris, CTHS, 2001, pp. 63-73.

80 This is a derogatory term for convicts. 
"People always talk about the bagne [...], I want to take responsibility for my own history [...]. Saint-Laurent's history is not only that of the bagne, it's also the village, where, you know, people live"81.

The history of the bagnes has almost become exogenous to Guyanese history. This cumbersome past, which is still very recent, has been too heavy a burden to be integrated into local memory. Then again, the recognition of that of slavery, although no lighter, has been part of a political and identity combat 'concerning' all the Guyanese. Lately, the authorities have launched new cultural heritage policies to restore the camps, update the archives and create museums in the former convict camps. These actions have sometimes tended to combine penal history with that of the 'others', as in the case of the Teremba museum in New Caledonia which has endeavoured to trace the history of the La Foa district by closely associating the fate of convicts with that of the Kanak. However, Guyana and New Caledonia have both inherited a complex past fuelling segregated and often rival memories. In both cases, writing a shared history which takes into account the connections and exchanges as well as the particularities of all remains a challenge.

\section{References :}

81 Interview with a person from Saint Laurent made by Les Voix de la Ville association, November 2012. 